\title{
Apo B Gene Haplotype is Associated With Lipid Profile of Higher Risk for Coronary Heart Disease in Caucasian Brazilian Men Marcos O. Machado, ${ }^{1 *}$ Mário H. Hirata, ${ }^{1}$ Marcelo C. Bertolami, ${ }^{2}$ and Rosario D.C. Hirata ${ }^{1}$ ${ }^{1}$ Department of Clinical and Toxicological Analysis, Faculty of Pharmaceutical Sciences, São Paulo University, São Paulo, Brazil \\ ${ }^{2}$ Institute of Cardiology Dante Pazzanese, São Paulo, SP, Brazil
}

\begin{abstract}
We investigated using haplotype analysis whether genetic variation of the apo $B$ gene is associated with a higher risk for coronary heart disease in a Brazilian population. Ins/ $\mathrm{Del}, \mathrm{Xbal}$, and EcoRl polymorphic sites of the apolipoprotein B (apo B) gene were studied in 67 patients with CHD and in 67 agematched healthy individuals selected from a population of Brazilians. The allelic frequency of apo B polymorphisms did not differ between the CHD patients and controls. However, a significant linkage disequilibrium was observed between the $\mathrm{Xbal}$ site and Ins/Del polymorphism of the apo B gene in CHD in-
\end{abstract}

Key Words: apolipoprotein B; DNA polymorphisms; atherosclerosis; lipoproteins; polymerase chain reaction

\section{INTRODUCTION}

Apolipoprotein B (apo B) is the major protein of human low-density lipoprotein (LDL) and very low density lipoprotein (VLDL). It is essential for the assembly, secretion, and metabolism of lipoprotein particles and also for removal of LDL from the circulation by receptor-mediated endocytosis via the LDL receptor (1). Therefore, apo B plays a central role in regulating plasma and cellular lipid levels.

Several authors (2-5) have examined an association between the variations of the apo B gene and serum lipid concentration and coronary heart disease (CHD). Data from several of these studies of the apo B polymorphic loci have provided preliminary evidence that some alleles may be associated with altered lipid levels and/or risk of atherosclerosis, while others have shown conflicting results $(6,7)$. In particular, the XbaI polymorphism in exon 26 of the apo B gene has been associated with increased of total cholesterol (TC) levels (8), altered postprandial lipoprotein metabolism (9), and with increased CHD $(10,11)$, although the underlying mechanism is unknown. Associations between the EcoRI polymorphism in exon 29 and variations in TC and triglyceride (TG) levels, obesity and CHD have also been reported $(3,5,12,13)$. Furthermore, the Ins/Del polymorphism of the signal peptide region of apo B gene has been associated with higher TG (14), TC, and LDL-cholesterol (LDL-C) levels $(15,16)$. It seems likely that most associations between lipid levels and apo B polymorphisms are due to linkage disequilibrium between these polymorphisms and some unknown causal mutations. Until now, studies of individual polymorphisms of the apo B gene have produced little consensus regarding the effect on lipid levels. Therefore, the aim of the present study was to investigate using haplotype analysis whether genetic variation of the apo $\mathrm{B}$ gene is associated with a higher risk for CHD in a Brazilian population.

\section{MATERIALS AND METHODS}

\section{Study Subjects}

\section{Patients}

During a 4-month period (March, 1997 to June, 1997), 67 unrelated Caucasian Brazilian patients of both sexes (43 males and 24 females) with a median age of 65 (range, 37-78) were

\footnotetext{
*Correspondence to: Marcos O. Machado, Faculty of Pharmaceutical Sciences, São Paulo University, 580 Professor Lineu Prestes Avenue, São Paulo, SP; Brazil, CEP 05508-900. E-mail: matriatholon@ hotmail.com Received 18 April 2000; Accepted 3 August 2000
} 
collected consecutively from patients entering the Institute of Cardiology Dante Pazzanese, São Paulo, Brazil. These individuals presented with CHD, as evaluated by coronary angiography, ECG, serum enzymes, and clinical. Seventy percent of the patients had suffered one or more episodes of myocardial infarction (MI). Patients with gastrointestinal, thyroid, liver, and renal disease or diabetes were excluded from the study. None of them had suffered a recent myocardial infarction (from 24 hours to 2 months prior to intake) and none was treated with lipid-lowering diet or drugs at the time of blood sampling for determination of lipid parameters.

\section{Controls}

A base-sample of 67 unrelated healthy Caucasian Brazilian subjects of both sexes (43 males and 24 females) with a median age of 58 (range, 40-78) were recruited to form the control group. They were selected during a 3-month period (July, 1997 to September, 1997), at São Paulo University, SESMET, and were ascertained to be healthy, following a medical examination and patient history. None had a history of diabetes or hypertension, and none exhibited signs of CHD upon clinical or laboratory investigation.

\section{DNA Analysis}

Following 12-h fast, $5 \mathrm{ml}$ of venous blood was drawn into tubes containing $1 \mathrm{~g} / \mathrm{L}$ ethylene diamine tetra-acetic acid (EDTA) and genomic DNA was prepared from leukocytes by a rapid nonenzymatic method developed in our laboratory (17). The genotypes at three polymorphic sites-Ins/Del at the signal peptide, $X b a I$ at exon 26, and EcoRI at exon 29in the apo $\mathrm{B}$ gene were determined using a polymerase chain reaction (PCR) methodology. Three sets of oligonucleotide primers amplifying selected regions within the Ins/Del, XbaI, and EcoRI polymorphic sites were synthesized according to Boerwinkle et al. (18). Amplification was carried out in a final volume of $100 \mu \mathrm{L}$ containing $0.5-1.0 \mu \mathrm{g}$ genomic DNA, $0.2 \mu \mathrm{mol} / \mathrm{L}$ of each primer, $200 \mu \mathrm{mol} / \mathrm{L}$ deoxynucleoside triphosphates set (dNTPs) with a reaction buffer recommended by the manufacturer (Pharmacia Biotech, Piscataway, NJ). The Ins/Del polymorphism was analyzed by amplifying segments of $93 / 84 \mathrm{bp}\left(25\right.$ cycles, $94^{\circ} \mathrm{C}$ for $1 \mathrm{~min}$ and $65^{\circ} \mathrm{C}$ for $1.5 \mathrm{~min}$ ) and were visualized on silver-stained $10 \%$ polyacrylamide gels. The XbaI polymorphism was analyzed by amplification of a 710-bp fragment $\left(30\right.$ cycles, $96^{\circ} \mathrm{C}$ for $1.5 \mathrm{~min}, 52^{\circ} \mathrm{C}$ for $1.5 \mathrm{~min}$, and $72^{\circ} \mathrm{C}$ for $1.5 \mathrm{~min}$ ), followed by 4 -h digestion with $\mathrm{XbaI}$ at $37^{\circ} \mathrm{C}$ that resulted in fragments of 433 and 277 $\mathrm{bp}$ in the presence of the cutting site (X+allele). For analysis of the EcoRI polymorphism, a fragment of 480 bp was amplified $\left(30\right.$ cycles, $96^{\circ} \mathrm{C}$ for $1.5 \mathrm{~min}, 52^{\circ} \mathrm{C}$ for $1.5 \mathrm{~min}$, and $72^{\circ} \mathrm{C}$ for $1.5 \mathrm{~min}$ ). After digestion with EcoRI, fragments of 253 and $277 \mathrm{bp}$ were produced in the presence of the cutting site (E+ allele). Digested fragments of XbaI and EcoRI poly- morphisms were visualized following electrophoresis on $2 \%$ agarose gels.

\section{Lipid and Lipoprotein Analysis}

Serum total cholesterol (TC) and triglycerides (TG) were measured by enzymatic methods using the manufacturer's protocol (Boehringer, Mannheim, Germany, and Merck, New Jersey, USA, respectively). Cholesterol of the high-density lipoprotein (HDL-C) was measured after precipitation of LDL and VLDL with $\mathrm{MgCl}_{2}$ and phosphotungstic acid (Boehringer). VLDL-cholesterol (VLDL-C) was calculated assuming the relation VLDL-C $=\mathrm{TG} / 2.18$ derived indirectly following TG measurement ( $\mathrm{mmol} / \mathrm{L}$ ), and LDL-cholesterol (LDL-C) was estimated according to equation of Friedwald et al. (19).

\section{Statistical Analysis}

Allelic frequencies and genotype distribution for each polymorphic site or haplotype were estimated by gene counting. The Chi-square $\left(\chi^{2}\right)$ test was used to test the Hardy-Weinberg equilibrium and the linkage disequilibrium between different polymorphisms, as well as differences in allelic frequencies between CHD and control groups. The Mann-Whitney test was used to compare age and serum lipid concentrations between CHD and control groups. A Kruskal-Wallis one-way analysis of variance was performed to evaluate differences in lipid levels among the genotypes or haplotypes. All statistical calculations were made utilizing SigmaStat 1.0 (Software Jandel Scientific). Results were considered to be statistically significant at the $P<0.05$ level.

\section{RESULTS}

Table 1 summarizes serum lipid profiles of 67 CHD patients (CHD group) and 67 healthy individuals (control group) from a sample of the Brazilian population. Significant differences between control and CHD in serum levels of TC, TG, LDL-C, VLDL-C, and HDL-C were detected. The TC/HDL$\mathrm{C}$ ratio was greater in the CHD group $(P<0.05)$.

The relative frequencies of the rare $\mathrm{Del}, \mathrm{X}+$ and $\mathrm{E}$ - alleles of the apo B polymorphism were similar between CHD and control groups (Table 2). The distribution of the studied polymorphisms was at Hardy-Weinberg equilibrium in both CHD and control groups. However, as shown in Table 3, a significant diallelic linkage disequilibrium between the Ins/Del and $X b a I$ sites of the apo B gene was detected only in the CHD group $\left(\chi^{2}=12.3 ; P<0.01\right)$. This finding was not observed for the other polymorphisms.

Apo B gene haplotypes were constructed based on these results. Individuals presenting at least one $\mathrm{X}+$ allele and $\mathrm{Del}$ allele were named $\mathrm{X}+\mathrm{Del}$ haplotype, while the other genotype compositions were named X-Ins haplotype. Data presented in Table 4 show that patients from the CHD group 
TABLE 1. Clinical characteristics and serum lipid concentrations in CHD and control groups

\begin{tabular}{lccc}
\hline & CHD & Control & $P$ \\
\hline Patients $(n)$ & 67 & 67 & - \\
Age (years) & $65(37-78)$ & $58(40-78)$ & NS \\
TC (mmol/L) & $6.42(3.83-13.52)$ & $4.34(2.81-5.22)$ & $<0.05$ \\
TG $(\mathrm{mmol} / \mathrm{L})$ & $3.55(1.53-23.21)$ & $2.15(0.84-5.54)$ & $<0.05$ \\
HDL-C $(\mathrm{mmol} / \mathrm{L})$ & $1.15(0.55-1.74)$ & $1.28(0.77-1.91)$ & $<0.05$ \\
LDL-C $(\mathrm{mmol} / \mathrm{L})$ & $4.31(2.54-5.12)$ & $2.87(1.43-3.56)$ & $<0.05$ \\
VLDL-C (mmol/L) & $0.71(0.32-2.01)$ & $0.43(0.15-1.11)$ & $<0.05$ \\
TC/HDL-C ratio & $5.8(3.0-18.0)$ & $3.4(1.0-6.0)$ & $<0.05$ \\
\hline
\end{tabular}

Values are medians. Range of values is presented in parentheses. NS = nonsignificant.

carrying the $\mathrm{X}+D e l$ haplotype had significantly higher TC, TG, and VLDL-C serum levels than those with X-Ins haplotype $(P<0.05)$.

In order to evaluate whether this effect was related to gender or age, individuals from the CHD group were regrouped and further analyzed. Figure 1 shows that those males with CHD carrying the $\mathrm{X}+\mathrm{Del}$ haplotype presented TC, TG, LDL$\mathrm{C}$ serum levels and a TC/HDL-C ratio greater than those with the X-Ins haplotype. This finding was not observed in the female group (Fig. 2). There was no association between apo B genotypes or haplotypes and age (data not shown), either in the CHD group or control group.

\section{DISCUSSION}

Previous reports have indicated an association between common DNA polymorphisms of the apo B gene and an el-

TABLE 2. Comparison of genotype distribution and relative allele frequences of Ins/Del, XbaI and EcoRI polymorphisms of the apo B gene between CHD and control groups

\begin{tabular}{|c|c|c|c|c|c|c|}
\hline \multirow{2}{*}{$\begin{array}{l}\text { Polymorphic } \\
\text { sites }\end{array}$} & \multirow[b]{2}{*}{ Genotypes } & \multicolumn{2}{|c|}{ CHD groups } & \multicolumn{2}{|c|}{ Control group } & \multirow[b]{2}{*}{$\chi^{2}$} \\
\hline & & Number & $\%$ & Number & $\%$ & \\
\hline \multirow[t]{4}{*}{ Ins/Del } & Ins/Ins & 28 & 41.8 & 28 & 41.8 & \\
\hline & Ins/Del & 30 & 44.8 & 33 & 49.2 & \\
\hline & Del/Del & 9 & 13.4 & 6 & 9.0 & \\
\hline & & \multicolumn{2}{|c|}{ Frequency } & \multicolumn{2}{|c|}{ Frequency } & \\
\hline \multirow[t]{2}{*}{ Allele } & Ins & \multicolumn{2}{|c|}{0.642} & \multicolumn{2}{|c|}{0.664} & 0.74 \\
\hline & Del & \multicolumn{2}{|c|}{0.358} & \multicolumn{2}{|c|}{0.335} & $P>0.05$ \\
\hline \multirow[t]{4}{*}{ XbaI } & $\mathrm{X}+\mathrm{X}+$ & 13 & 19.4 & 8 & 12.0 & \\
\hline & $X+X-$ & 37 & 55.2 & 35 & 52.2 & \\
\hline & $X-X-$ & 17 & 25.4 & 24 & 35.8 & \\
\hline & & \multicolumn{2}{|c|}{ Frequency } & \multicolumn{2}{|c|}{ Frequency } & \\
\hline \multirow[t]{2}{*}{ Allele } & $\mathrm{X}+$ & \multicolumn{2}{|c|}{0.470} & \multicolumn{2}{|c|}{0.380} & 2.44 \\
\hline & $\mathrm{X}-$ & \multicolumn{2}{|c|}{0.530} & \multicolumn{2}{|c|}{0.620} & $P>0.05$ \\
\hline \multirow[t]{4}{*}{ EcoRI } & $\mathrm{E}+\mathrm{E}+$ & 45 & 67.2 & 49 & 73.1 & \\
\hline & $\mathrm{E}+\mathrm{E}-$ & 18 & 26.9 & 16 & 23.9 & \\
\hline & E-E- & 4 & 5.9 & 2 & 3.0 & \\
\hline & & \multicolumn{2}{|c|}{ Frequency } & \multicolumn{2}{|c|}{ Frequency } & \\
\hline \multirow[t]{2}{*}{ Allele } & $\mathrm{E}+$ & \multicolumn{2}{|c|}{0.806} & \multicolumn{2}{|c|}{0.850} & 1.19 \\
\hline & E- & \multicolumn{2}{|c|}{0.194} & \multicolumn{2}{|c|}{0.150} & $P>0.05$ \\
\hline
\end{tabular}

TABLE 3. Linkage disequilibrium analysis between $\mathrm{XbaI}$ and Ins/Del polymorphisms of apo B gene in CHD group

\begin{tabular}{|c|c|c|c|c|c|c|}
\hline & \multirow[b]{2}{*}{ Genotypes } & \multicolumn{3}{|c|}{ XbaI } & \multirow[b]{2}{*}{ Total } & \multirow[b]{2}{*}{$\chi^{2}$} \\
\hline & & $\begin{array}{c}X-X- \\
(n)\end{array}$ & $\begin{array}{c}\mathrm{X}+\mathrm{X}- \\
(\mathrm{n})\end{array}$ & $\begin{array}{c}\mathrm{X}+\mathrm{X}+ \\
\text { (n) }\end{array}$ & & \\
\hline \multirow{4}{*}{ Ins/Del } & Ins/Ins & 9 & 13 & 6 & 28 & \\
\hline & Ins/Del & 7 & 21 & 2 & 30 & 12.3 \\
\hline & Del/Del & 1 & 3 & 5 & 9 & $(P<0.01)$ \\
\hline & Total & 17 & 37 & 13 & 67 & \\
\hline
\end{tabular}

$\mathrm{n}=$ number of individuals.

evated risk for CHD $(2,3)$. Consequently, the apo B gene has been implicated as a candidate gene for atherosclerosis (3). However the suspected association between apo B polymorphisms and CHD risk has not been consistently observed in all studied populations.

In the Brazilian population, a lack of association between CHD and the allelic frequencies of each isolated polymorphism of apo B gene has been observed in previous studies (20) and is supported by our present work.

The association between the $\mathrm{X}+$ allele and elevated serum lipid levels found in some Caucasian populations $(9,18,21)$ has not been observed in other Caucasian populations $(4,12,20,22)$, Koreans (16), or black Africans (23). Our present data support a lack of association in Caucasian Brazilians. These conflicting data were analyzed by Humphries and Talmud (24). According to these authors, the genetic characteristic of sample, gene-environment interaction, gene-gene interaction, and the type of statistical methods utilized were the major interstudy variables contributing to the conflicting results. The mutation that creates the $\mathrm{XbaI}$ restriction site does not alter an amino acid sequence and cannot therefore directly affect lipid metabolism. This polymorphism is consequently presumed to be a marker in linkage disequilibrium with a functional mutation in the apo B gene itself or in a neighboring sequence that affects cholesterol levels.

The Ins/Del polymorphism of the apo B gene has been in-

TABLE 4. Lipid profiles in relation to $\mathrm{X}+\mathrm{Del}$ and $\mathrm{X}-\mathrm{Ins}$ haplotypes of apo B gene in individuals of CHD group

\begin{tabular}{lccc} 
& \multicolumn{3}{c}{ Haplotypes } \\
\cline { 2 - 3 } $\begin{array}{l}\text { Lipid } \\
\text { parameters }\end{array}$ & $\begin{array}{c}\mathrm{X}+\text { Del } \\
(\mathrm{n}=30)\end{array}$ & $\begin{array}{c}\mathrm{X} \text {-Ins } \\
(\mathrm{n}=37)\end{array}$ & $P$ \\
\hline TC $(\mathrm{mmol} / \mathrm{L})$ & $6.85(4.73-9.43)$ & $5.84(3.82-13.73)$ & 0.02 \\
TG $(\mathrm{mmol} / \mathrm{L})$ & $4.21(1.99-9.80)$ & $2.84(1.57-7.18)$ & 0.01 \\
HDL-C $(\mathrm{mmol} / \mathrm{L})$ & $1.06(0.56-1.65)$ & $1.11(0.57-1.78)$ & $\mathrm{NS}$ \\
LDL-C $(\mathrm{mmol} / \mathrm{L})$ & $4.50(2.76-7.39)$ & $4.11(2.53-11.95)$ & $\mathrm{NS}$ \\
VLDL-C (mmol/L) & $0.85(0.38-1.96)$ & $0.56(0.31-1.45)$ & 0.01 \\
CT/HDL-C ratio & $6.5(3.2-13.1)$ & $5.2(3.1-18.2)$ & $\mathrm{NS}$ \\
\hline
\end{tabular}

Values are medians (minimum - maximum). $\mathrm{n}=$ number of individuals. NS $=$ non-signfiicant.

$\mathrm{X}+$ Del $=\mathrm{X}+\mathrm{X}+$ Del/Del, $\mathrm{X}+\mathrm{X}+I n s / D e l, \mathrm{X}+\mathrm{X}-I n s / D e l, \mathrm{X}+\mathrm{X}-$ Del/Del. $\mathrm{X}-I n s$ $=\mathrm{X}-\mathrm{X}-I n s / I n s, \mathrm{X}-\mathrm{X}-I n s / D e l, \mathrm{X}-\mathrm{X}-D e l / D e l, \mathrm{X}+\mathrm{X}-I n s / I n s, \mathrm{X}+\mathrm{X}+I n s / I n s$. 


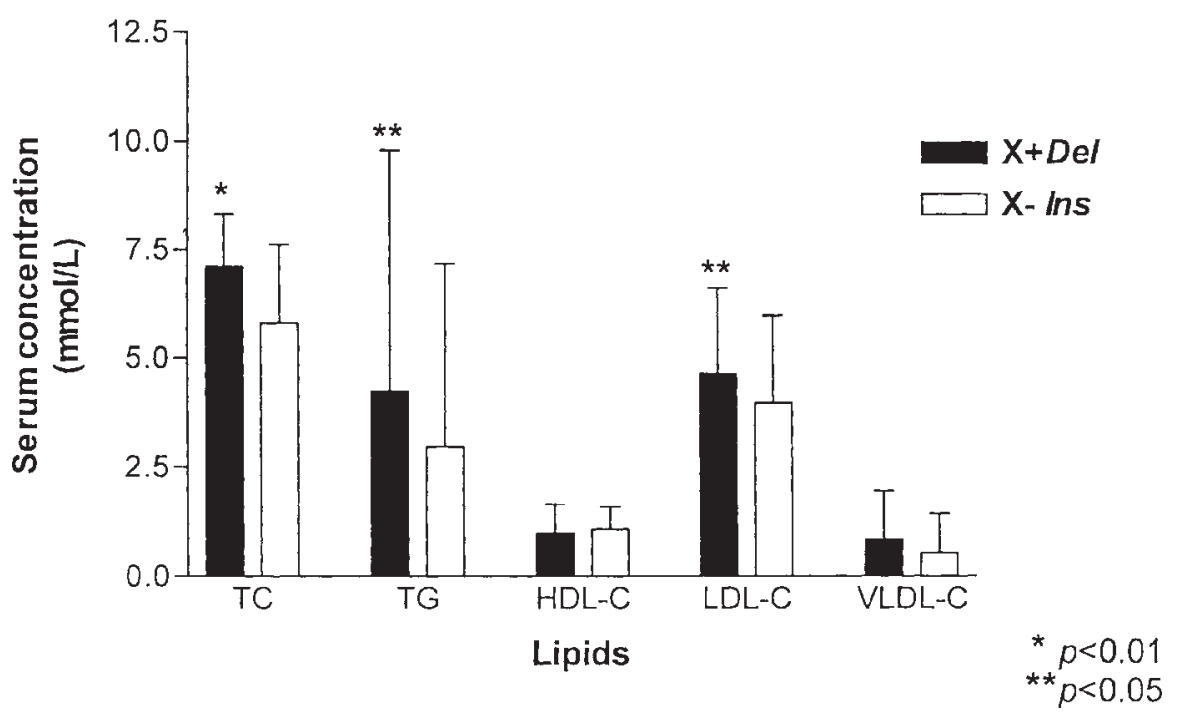

Fig. 1. Serum lipid profiles in males of the CHD group with $\mathrm{X}+$ Del and $\mathrm{X}-$ Ins haplotypes of apo B gene. Error bars represent maximum values for each lipid.

vestigated in a number of studies with different populations (25-27). Although some studies have shown an increased frequency of the $\mathrm{Del}$ allele in patients with CHD compared with control individuals (28), this was not observed in others (15). The Del allele has been associated with higher apo B plasma levels (29), lipid levels, and body mass index (30) indicating a higher risk for CHD. In our study, the allelic or genotypic frequency of the Ins/Del polymorphism was not associated with either CHD or with variation in serum lipid profile as was observed by other authors (31). However, when the rare $\mathrm{Del}$ allele was combined with $\mathrm{X}+$ allele, there was a strong association of these two polymorphisms with a lipid profile of higher risk for CHD. This is consistent with the observed linkage disequilibrium between these two apo B polymorphisms in the CHD group, as also found in other studies $(23,25,27,32)$. The mechanism underlying the effect of the Del allele on lipid serum levels or high risk for CHD is not completely understood. It was proposed that the three amino acids leu-ala-leu excluded in the apo B Deletion $(\mathrm{Del})$ allele may alter the rate of translocation of newly synthesized apo B from cytoplasm into the endoplasmic reticulum (14), affecting the rate of biosynthesis and secretion of apo $B$ protein from hepatocytes in the form of LDL or $\operatorname{Lp}(a)(33,34)$.

The effect of the $X+D e l$ haplotype on the lipid profile of males from the CHD group observed in our study was also found in a population from Denmark (21). It was shown that

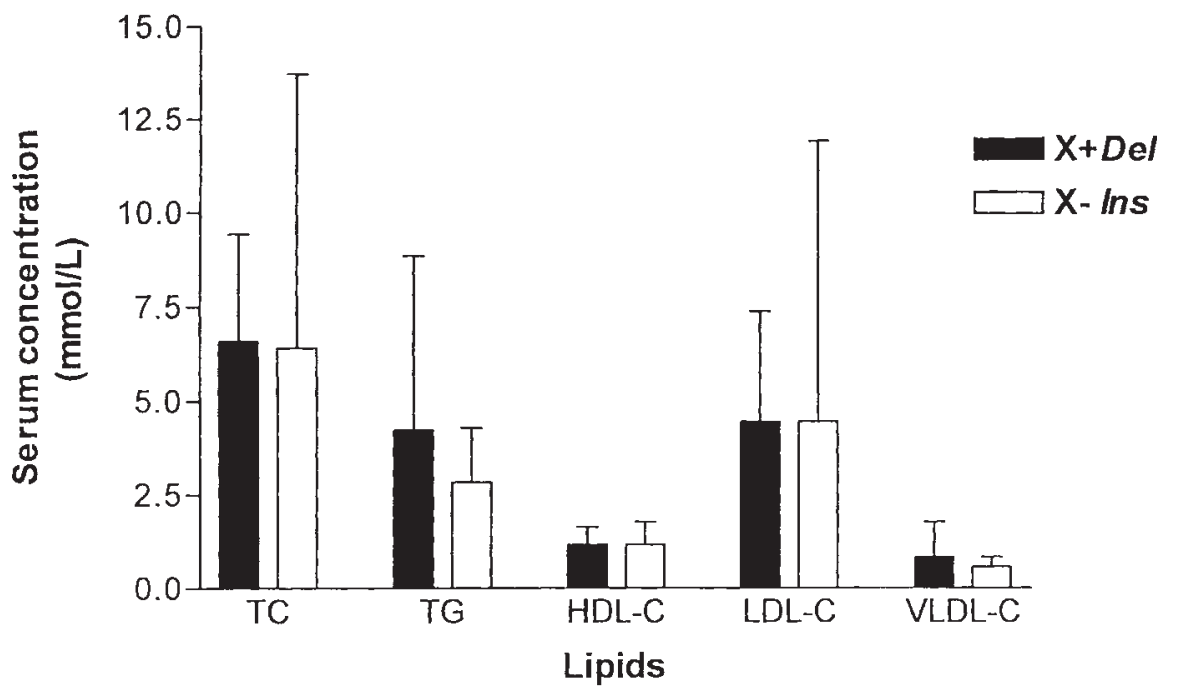

Fig. 2. Serum lipid profiles in females of the CHD group with $\mathrm{X}+$ Del and $\mathrm{X}-$ Ins haplotypes of apo $\mathrm{B}$ gene. Error bars represent maximum values for each lipid. 
younger male patients with CHD and moderate hypercholesterolemia had the highest frequency of haplotypes including both the $\mathrm{X}+$ and the $\mathrm{Del}$ alleles. More recently, Anderson et al. 1997 (23) found similar results in a population from Africa, in which males and females were analyzed separately. These data indicated that haplotypes formed by XbaI and Ins/ Del polymorphisms were responsible for interindividual variation in serum lipoprotein and lipid levels in the African population. The results of these previous investigations $(21,23)$ emphasize the importance of considering age and sex in genotype association studies.

Although we did not observe an influence of age variation in the effect of $X+D e l$ haplotype on lipid parameters, we did find that significant increases in serum lipid due to the $X+D e l$ haplotype were restricted to males.

Thus, the data from this study suggest that pooling genders and adjusting for gender effects can remove potentially important genetic information and should be avoided. It is noteworthy that the influence of estrogen levels observed in association with patterns involving CHD-risk-related traits might be relevant to gender differences in CHD risk, which is known to increase in postmenopausal women.

In conclusion, this study indicates that the $X+D e l$ haplotype of the apo B gene contributes to variation in CHD-riskrelated lipid and lipoprotein profile in men with CHD from a sample of the Caucasian Brazilian population. Therefore, the $X+D e l$ apo B haplotypes may be helpful in identifying individuals with an increased CHD risk.

\section{ACKNOWLEDGMENTS}

We would like to thank Dr. Paulo Otto for his expert statistical advice, Yara Nakamura, Francesca Theobaldo, Luis A. Salazar, and Elizabeth C.R. Guzmán for assistance in collecting the samples and Dr. Donald Sellitti for his revisions and suggestions. Marcos O. Machado was the recipient of a fellowship from CNPq-Brazil.

\section{REFERENCES}

1. Brown MS, Goldstein JL. A receptor-mediated pathway for cholesterol homeostasis. Science 1986;232:34-47.

2. Law A, Powell LM, Brunt H, et al. Common DNA polymorphism within the coding sequence of apolipoprotein $\mathrm{B}$ gene associated with altered lipid levels. Lancet 1986;1:1301-1303.

3. Paulweber B, Friedl W, Krempler F, Humphries SE, Sandhofer F. Association of DNA polymorphism at the apolipoprotein B gene locus with coronary heart disease and serum very low density lipoprotein levels. Atherosclerosis 1990;10:17-24.

4. Hegele RA, Huang LS, Hebert PN, et al. Apolipoprotein B gene DNA polymorphism associated with myocardical infarction. N Engl J Med 1986;315:1509-1515.

5. Genest Jr JJ, Ordovas JM, Mcnamara JR, et al. DNA polymorphism of the apolipoprotein B gene in patients with premature coronary artery disease. Atherosclerosis 1990;82:7-17.

6. Darnfors C, Wiklund O, Nilsson J, et al. Lack of correlation between the apolipoprotein B XbaI polymorphism and blood lipid levels in a Swedish population. Atherosclerosis 1989;75:183-187.
7. Aburatani H, Matsumoto A, Itoh H, et al. A study of DNA polymorphism in the apolipoprotein B gene in a Japanese population. Atherosclerosis 1988;72:71-76.

8. Bohn MB, Bakken J, Berg K. XbaI polymorphism in DNA at the apolipoprotein B locus is associated with myocardial infarction (MI). Clin Genet 1993;44:241-248.

9. Lopez-Miranda J, Ordovas JM, Ostos MA, et al. Dietary fat clearance in normal subjects is modulated by genetic variation at the apolipoprotein B genes locus. Arterioscler Thromb Vasc Biol 1997;17(9):1765-1773.

10. Ukkola O, Savolanien MJ, Salmela PI, Von Dickhoff K, Kesaniemi YA. Apolipoprotein B gene DNA polymorphisms are associated with macroand microangiopathy in non-insulin-dependent diabetes mellitus. Clin Gen 1993;44:177-184.

11. Myant NB, Gallagher J, Barbir M, Thompson GR, Wile D, Humphries SE. Restriction fragment length polymorphisms in the apo B gene in relation to the coronary artery disease. Atherosclerosis 1989;77:193-201.

12. Stepanov VA, Puzyrev VP, Karpov RS, Kutmin AI. Genetic markers in coronary heart disease in a Russian population. Hum Biol 1998; 70(1):47-57.

13. Pouliot M-C, Després, J-P, Dionne FT, et al. Apo B-100 gene EcoRI polymorphism: relations to plasma lipoprotein changes associated with abdominal visceral obesity. Arterioscler Thromb 1994;14:527-533.

14. Xu C-F, Tikkanen MJ, Huttunen JK, et al. Apolipoprotein B signal peptide insertion/Desetion polymorphism is associated with $\mathrm{Ag}$ epitopes and involved in the determination of serum triglyceride levels. J Lipid Res 1990;31:1255-1261.

15. Bohn M, Bakken A, Erissen J, Berg K. The apolipoprotein B signal peptide insertion/DELETION polymorphism is not associated with myocardial infarction in Norway. Clin Genet 1994;45:255-259.

16. Hong SH, Lee CC, Kim JQ. Genetic variation of the apolipoprotein B gene in Korean patients with coronary artery disease. Mol Cells 1997;7:521-525.

17. Salazar LA, Hirata MH, Cavalli SA, Machado MO, Hirata RDC. Optimized procedure for DNA isolation from fresh and cryopreserved clotted human blood useful in clinical molecular testing. Clin Chem 1998;44:1748-1750.

18. Boerwinkle E., Lee SS, Butler R, Schumaker VN, Chan L. Rapid typing of apolipoprotein B DNA polymorphisms by DNA amplification. Atherosclerosis 1993;81:225-232.

19. Friedewald WT, Levy RI, Fredrickson DS. Estimation of the concentration of low-density lipoprotein cholesterol in plasma, without use of the preparative ultracentrifuge. Clin Chem 1972;18:499-502.

20. Bydlowski SP, Novak EM, Issa JS, Forti N, Giannini SD, Diament J. DNA polymorphisms of apolipoprotein B and AI-CIII-AIV genes in a Brazilian population: a preliminary report. Braz Med Biol Res 1996;29:1269-1274.

21. Hansen PS, Klausen IC, Lemming L, Gerds LU, Gregersen N, Faergeman O. Apolipoprotein B gene polymorphism in ischemic disease and hypercholesterolemia: effects of age and sex. Clin Genet 1994;45:78-83.

22. Wiklund O, Darnfors C, Bjursell G, et al.XbaI restriction fragment length polymorphism of apolipoprotein B in Swedish myocardial infarction patients. Eur J Clin Invest 1989:19:255-258.

23. Anderson JL, Bunker CH, Aston CE, Kamboh MI. Relationship of two apolipoprotein B polymorphisms with serum lipoprotein and lipid levels in African blacks. Hum Biol 1997;69:793-807.

24. Humphries SE, Talmud PJ. Hyperlipidaemia associated with genetic variation in the apolipoprotein B gene. Curr Opin Lipid 1995;6:215-222.

25. Renges HH, Wile DB, Mckeigue PM, Marmot MG, Humphries SE. Apolipoprotein B gene polymorphisms are associated with lipid levels in men of South Asian descent. Atherosclerosis 1991;91:267-275.

26. Saha N, Tay JSH, Chew LS. Influence of apolipoprotein B signal peptide insertion/DeLetion polymorphism on serum lipids and apolipoproteins in a Chinese population. Clin Genet 1992;41:152-156.

27. Ye P, Chen B, Wang S. Association of polymorphism of the 


\section{Machado et al.}

apolipoprotein B gene with coronary heart disease in Han Chinese. Atherosclerosis 1995; 117:43-50.

28. Wu JH, Wen MS, Lo SK, Chern MS. Increased frequency of apolipoprotein B signal peptide $s p 24 / 24$ in patients with coronary artery disease. General allele survey in the population of Taiwan and comparison with Caucasians. Clin Genet 1994;45:250-254.

29. Gardemann A, Ohly D, Fink M, et al. Association of the insertion/deletion gene polymorphism of the apolipoprotein B signal peptide with myocardial infarction. Atherosclerosis 1988;141:167-175.

30. Marshall HW, Morrison LC, Wu LL, et al. Apolipoprotein polymorphism fails to define risk of coronary disease. Results of a prospective, angiographically controlled study, Circulation 1994;89: $567-577$.
31. Gafney D, Freeman DJ, Shepherd J, Packard CJ. The INS/DEL polymorphism in the signal sequence of apolipoprotein B100: a mutation of apolipoprotein B that causes hypercholesterolemia. J Lipid Res 1990;31:1337-1349.

32. Saha N, Tay JSH, Humphries SE. DNA polymorphisms of the apolipoprotein B gene are associated with obesity and serum lipids in healthy Indians in Singapore. Clin Genet 1993;44:113-120.

33. Randall LL, Hardy SJS. Unity in function in the absence of consequence in sequence: role of leader peptides in export. Science 1989; 243:1156-1159.

34. Visvikis S, Cambou JP, Arveiler D, et al. Apolipoprotein B signal peptide polymorphism in patients with myocardial infarction and controls. “The ECTIM Study." Hum Genet 1993;90:561-565. 